\title{
礫床流路における非定常掃流砂量
}

\section{UNSTEADY BED-LOAD TRANSPORT IN GRAVEL-BED OPEN CHANNEL}

\author{
辻 本 哲 郎* \\ By Tetsuro TSUJIMOTO
}

\begin{abstract}
Bed-load transport at unsteady flow is studied. In gravel-bed streams, the direct effect of flow unsteadiness on bed-load motion promotes the transport discharge and brings positive or negative phase shift. Meanwhile, in sand beds with dunes, the relaxation effect suppresses the sediment discharge and causes the phase lag. Particularly in gravel beds, steep hydrograph often appears, and the former effect dominates. The linear analysis reveals that the amplification of bed-load discharge is reversally proportional to the dimensionless time scale of hydrograph, and that it is correlated to the intensity of phase shift. With the increase of the Froude number and the ratio of bed slope to the relative flow depth, the phase shift increases to become positive. The analytical results are qualitatively well consistent with the flume experiments, and they are helpful to obtain semi-empirical predicting formula for unsteady effect of bed-load transport.

Keywords : bed-load transport, unsteady sediment transport, unsteady flow, transient process, gravel bed, linear analysis
\end{abstract}

\section{1.まえがき}

近年，より高度な河川管理が求められるとき，より複 雑な条件での流砂および移動床現象についての理解, 説 明そして予測が要請されるようになってきている. 従来 の流砂量式は定常等流状態の流れに対し平衡状態に達し た河床での流砂量を予測するもので，これまでは，少な くとも第一次近似的にはそれが流砂の運動方程式として 代用できるとし，流砂の連続式と連立させてさまざまな 移動床現象を説明・予測しようとしてきた.しかし，こ うした近似が十分でない場合や，より精度良い予測の必 要性が指摘される場合がある．流れの非定常性や不等流 効果, あるいは流砂・移動床現象の緩和過程（応答遅れ） に起因する非平衡効果が，流砂が時間的・場所的に変わ る過程 (transient process of sediment transport) に 及ぼす影響は，最近の移動床水理学の分野で特に注目さ れ，また研究の必要性が強く指摘されているトピックス の 1 つであろ ${ }^{1) ~ 5)}$. 本研究は ${ }^{21)}$, 何らかのハイドログラ フをもった開水路非定常流れに対する掃流砂量の非定常 性を検討するものであり，特に礫床急勾配水路で鋭い八 イドログラフを対象とした（本論文ではスイス連邦工科

* 正会員 工博 金沢大学助教授 工学部土木建設工学科 （开920 金沢市小立野 2-40-20）
大学ロザンヌ校で行われた Suszka ${ }^{8}$ による水路実験の 結果を主たる検討素材とする). なお，これと比較する形 で緩勾配砂床水路で緩い変化のハイドログラフに対する 掃流砂量の非定常性についても簡単に述べる.

非定常開水路流れについては, 古典的な水理学の手法 (一次元解析) で導かれたいわゆる Saint-Venant 方程式

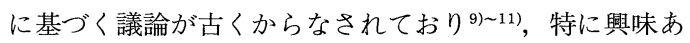
る結果として洪水の最高水位, 最大流速, 最大流量の到 達順位についての予测・説明などがされている，しかし， 非定常開水路流れの構造 (たと之ば流速分布や乱れ特性) についての議論 ${ }^{12)}$ は最近緒についたばかりといってよい ほどである.

非定常流の条件での流砂量の変化についての基礎的知 見も，必ずしもこれまで十分には得られていない．特に 浮遊砂やウォッシュロードを含む場合に, 洪水のピーク の前に流砂量のピークが観測されることなどが指摘され ている13),14)ものの, こうした効果の出現機構についての

注 1 ）本論文の一部（特に2.で非定常効果を 2 種類に分類 している部分）は第 32 回水理講演会吕および第 6 回国際水理 学会・アジア太平洋会議》で発表しているが, 本論文では, 特 に碟床水路での鋭いハイドログラフ下での非定常流砂量に焦 点を絞って議論を発展させ, またそれについての実験結果との 対照を拡充している. 
研究はこれまでほとんどないし，一方掃流砂については その効果が一般には小さいため研究例は少ない.

Phillips and Sutherland ${ }^{15), 16)}<$ Graf and Susz$\mathrm{ka}^{8), 17), 18}$ は実験水路で非定常流量に対する掃流砂量の時 間的変化を詳細に調べている. Phillips ら ${ }^{15), 16)}$ は砂を用 いた実験を行って河床の変化（上流端洗掘や河床波の発

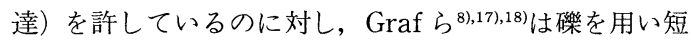
い時間内（鋭いハイドログラフ）に実験を終え，平坦河 床の条件となっている．前者ではむしろ河床の変形の遅 れを本質とする緩和過程が現われているようであり，実 際顕著な非定常効果が出現している。こうした遅れ現象 は移動床では重要な働きをすることから, 主として dunes を伴う移動床流れの非定常特性が検討されている が19) 21)，それらと本質的に同一の機構に基づくものと推 測される.これに対し Graf らの実験では, 河床波の効果 うとしているが，それゆえ非常に鋭いハイドログラフの 場合に限って非定常効果が現われる結果となっている. しかし，山間部などでこのような鋭いハイドログラフが 実際に出現していることが, 例を挙げて示されている8

Graf and Suszka ${ }^{17), 18}$ は, 次元解析的検討から, 流砂 量に対する非定常効果を表わす無次元指標をまず定義 し，これを規定する無次元パラメーターを選びそしてこ れらの間に回帰式を求めた. 非定常効果の出現機構に対 する見通しはこうした研究方法では得られないが，水理 学的に合理的にこの種の問題にアプローチした最初のも のとして評価される. Graf らのこの回帰式が現地データ をもほぼ説明することが Paul and Dhillon ${ }^{19}$ によって報 告されている。一方, Tingsanchali and Rana ${ }^{20)} は \mathrm{Graf}$ らの手法をそのまま掃流砂量に対する不等流効果の評価 を除去し，掃流機構そのものにかかわるものを抽出しよ

に適用している（が，不等流効果については問題がより 容易であるためむしろ解析的手法がとられるべきだろ う).

本研究では, 掃流砂を対象にし, 非定常開水路流れに 対応する流砂量の時間的変化について検討する，掃流砂 量は底面せん断応力（掃流力）で規定されるが，定常等 流下で掃流力と水深は一対一に対応づけられ，それゆ之 与之られた河床材料と勾配に対しては，流砂量は水深の 関数として書ける. 非定常流とそれに対する流砂量の変 化の性質を，水深の時間的変化を表わすハイドログラフ と流砂量の時間的変化の比較という形で検討を進める.

\section{2 . 掃流過程に対する 2 種類の非定常効果注2)}

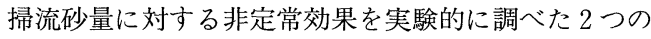
典型的な例8),15)を比較してみよう. Fig. 1，2にこれらの 実験結果の例を，八イドログラフに対して各時刻で定常 等流を仮定して計算される流砂量の時間的変化と，実際 の流砂量の時間的変化の比較で示した。

Fig. 1 の例は Graf and Suszkaによるもの)で(a)で は流砂量の変化がハイドログラフより遅れており，(b) では先行しているものの, 洪水期の累積流砂量は定常等 流として予測されるものより常に大きい.一方, Fig. 2 の 例は，Phillips and Sutherlandによるもの ${ }^{15)}$ で，常に実 際の流砂量は八イドログラフに対して遅れを呈し, 累積 流砂量は定常等流を仮定したものに比べ小さくなってい る. Graf and Suszka ${ }^{8}$ の実験は碷 $(d=12.2,23.5 \mathrm{~mm}$;

注 2 ) 本章の内容については，第 32 回水理講演会6)で発表 済みであるが, 礫の流送における非定常効果の特徵を浮き彫り にするため, 2 種類の非定常効果の分類と比較について説明し た.

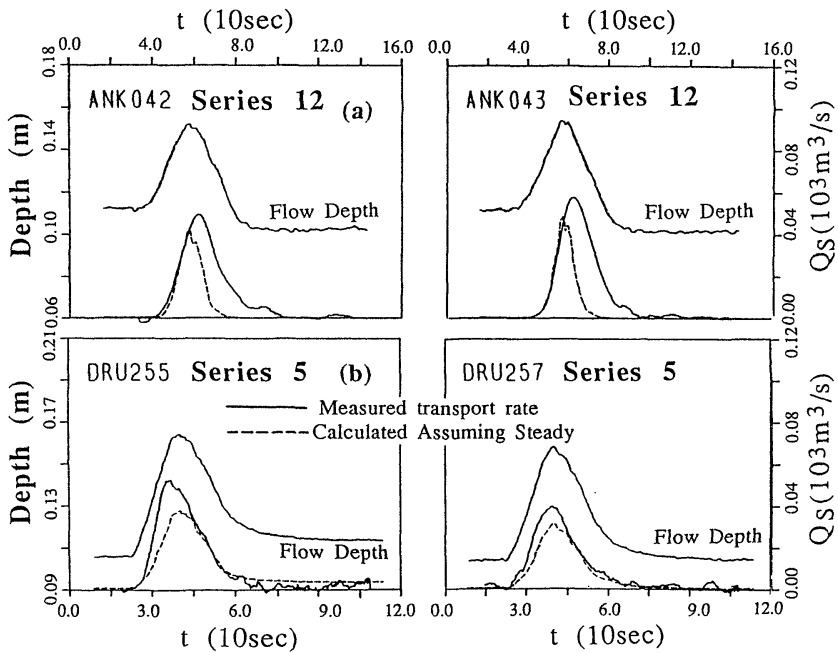

Fig. 1 Time variation of bed-load discharge in flat gravel bed (Graf et al.).

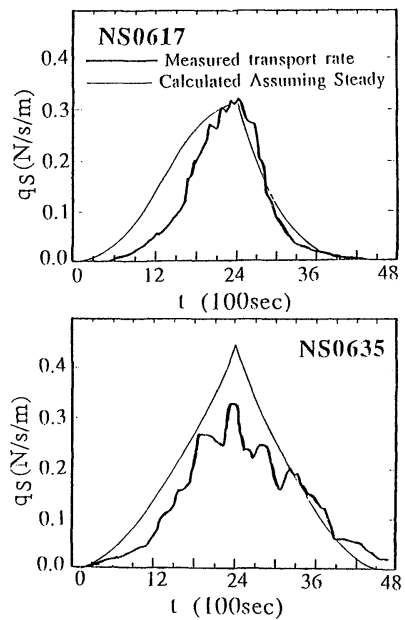

Fig. 2 Time variation of bed-load discharge in sand bed with dunes (Phillips et al.). 
$d$ : 粒径)を用いた鋭いハイドログラフに対する (実験中 において平坦河床が保たれている）流砂量の変化である


発達時間程度の時間スケール (中川・辻本 ${ }^{20)}$ あるいは Yalin and Bishop ${ }^{24)}$ の研究より類推される）のハイドロ グラフに対する砂 $(d=1.8 \mathrm{~mm})$ を用いた実験で, 河床 変形固有の緩和過程が現われていると考えられるもので ある.こうした条件の違いが, 掃流砂量の時間的変化に 上述の違いをもたらしたことは, 定性的に次のように説 明される6).

いま, 簡単のため水深の変化を次のような正弦波で表 わし, 変動振幅を微小量として線形近似で解析的に検討 を進めることとする.

$$
h(x, t)=h_{0}+h^{\prime}=h_{0}\left[1+\eta_{0} \sin (\omega t-\chi x)\right]
$$

ここに, $h$ : 水深, $\omega$ : 変動の角周波数, $x$ : 角波数であ $\eta$, また添字 0 は非擾乱值を示す. 流砂量 $q_{s}$ の変化も線 形近似下では次のように書ける.

$q_{s}(x, t)=q_{s 0}\left[1+\alpha \beta \eta_{0} \sin (\omega t-x x-\phi)\right] \cdots$

ここに, $\phi$ は流砂量変化のハイドログラフに対する位相 差である. 掃流砂量は河床材料が与えられているとき掃 流力の関数となるが, 水路勾配が一定のとき定常等流下 では掃流力は水深と一対一に対応するから, 水深の関数 と考えてもよい.このとき非定常効果を無視すれば, 流 砂量の変化は次のように書ける.

$$
q_{s}(x, t)=q_{s 0}\left[1+\beta \eta_{0} \sin (\omega t-\chi x)\right]
$$

ただし, $\beta$ は,

$$
\beta=\left(d q_{s} / d h\right)_{0} \cdot\left(h_{0} / q_{s 0}\right)
$$

のように, 定常等流下の平衡流砂量式 $\left(q_{s} \sim h\right.$ 関係) に よって決まる. 言い換えれば式 (2)における $\alpha, \phi$ が非定 常効果を表わしている.

掃流砂量に対する水流の非定常効果は, $d h / d t=\partial h / \partial t$ $+c \partial h / \partial x$ と書けるから, 形式的に,

$$
q_{s}(x, t)=q_{s}(h, d h / d t)=q_{s}(h, \partial h / \partial t, c \cdot \partial h / \partial x) \cdots(5)
$$

と書け ( $c=\omega / x$ : 変動の伝播速度), 線形化すると次のよ うに表わされる。

$$
q_{s}(x, t)=q_{s 0}\left[1+\beta\left(\frac{h^{\prime}}{h_{0}}+p_{1} \frac{\partial h}{\partial x}+\frac{p_{2}}{u_{* 0}} \frac{\partial h}{\partial t}\right)\right]
$$

ここに, $u_{*}$ : 摩擦速度であり， $p_{1}, p_{2}$ は非定常流れの運 動方程式により決定されるはずのものである. 水深の変 化が式 (1)のように表わされるときの流砂量変化は, 次 のようになる.

$$
q_{s}(x, t)=q_{s 0}\left[1+\alpha_{1} \beta \eta_{0} \sin \left(\omega t-\chi x-\phi_{1}\right)\right]
$$
ただし，

$$
\alpha_{1}=\sqrt{1+\lambda_{0}^{2}}>1
$$

$\phi_{1}=\arctan \lambda_{0} ; \quad \lambda_{0}=\left(p_{1} \varkappa-p_{2} \omega / u_{* 0}\right) h_{0}$

であり, この結果は, 非定常効果として流砂量振幅の増 幅 $\left(\alpha_{1}>1\right)$ が生じること, 八イドログラフとの位相差は



Fig. 3 Direct effect of flow unsteadiness on bed-load transport.

$p_{1}, p_{2} \omega / u_{* 0}$ に応じて正にも負にもなることを表わして おり (Fig. 3 参照), 河床変形の効果を除去した Graf and Suszka の実験結果 ${ }^{8)}$ (Fig. 1) を定性的に説明している. 河床変形に時間を要することによる遅れ現象は, イン パルス応答を用いて巧みに表現される5),20). 水理条件と しての水深変化に対する掃流砂量変化のインパルス応答 を $g_{R}(\tau)$ と書くと, 任意の水深変化に対する流砂量の応 答的変化は次のように表わされる.

$$
q_{s}(x, t)=q_{s 0}\left\{1+\int_{0}^{\infty} \frac{h^{\prime}(x, t-\tau)}{h_{0}} g_{R}(\tau) d \tau\right\} \cdots \cdots
$$

式 (1) で表わされるような正弦波状の水深変化に応答す る流砂量変化は, 結局次のようになる.

$$
q_{s}(x, t)=q_{s 0}\left[1+\alpha_{2} \beta \eta_{0} \sin \left(\omega t-\chi x-\phi_{2}\right)\right]
$$

ただし，緩和過程が指数関数的に表わされるものとし， 次のようにインパルス応答を定式化した.

$$
g_{R}(\tau)=\left(1 / \Lambda_{T}\right) \exp \left(-\tau / \Lambda_{T}\right)
$$

ここに, $\Lambda_{T}$ は緩和の時間スケールで, 河床波の発達時間 スケール20),24)に相当する.このとき，

$$
\begin{aligned}
& \alpha_{2}=1 / \sqrt{1+\left(\omega \Lambda_{T}\right)^{2}}<1 \\
& \phi_{2}=\arctan \left(\omega \Lambda_{T}\right) \cdots \cdots \cdots
\end{aligned}
$$

であり，掃流砂量の変動振幅は常に抑制され，また常に 第 1 象限に属する位相遅れが出現することとなり (Fig. 4 参照), Phillips and Sutherland ${ }^{15)}$ の実験結果 (Fig. 2)

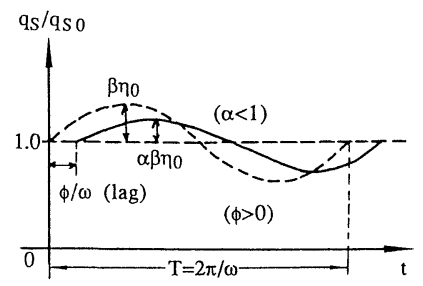

Fig. 4 Relaxation effect bed-load transport. 
を定性的に良く説明している。

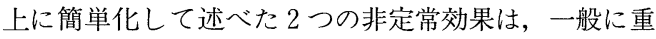
畳することが多いが，Graf and Suszka ${ }^{8}$ および Phillips and Sutherland ${ }^{15)}$ 実験ではおのおののタイプがうまく 卓越して抽出された. 以上の結果，一般的に次のような 推測ができよう．緩勾配の砂河床では第 2 の夕イプが卓 越し，河床波の発達時間に匹敵するような時間スケール のハイドログラフに対して流砂量変化は顕著な遅れを呈 し，変動強度は抑制される。これに対し急勾配の礫床で は，一般にハイドログラフが鋭いため河床変形が顕著で なかったり対象とする短時間の間では無視されることが 多く, また水流の非定常効果が強くなって, 第 1 の夕イ プの効果が卓越，すなわち条件によっては流砂量のピー クがハイドログラフのそれより先行したり遅れたりする が，変動強度は常に増幅される。

\section{3. 非定常流れによる磁の掃流量}

本章では，礫の掃流に及ぼす水流の非定常性の影響に ついて，前章の第 1 のイプについての解析をさらに進 める。すなわち，式 $(6)$ に含まれるパラメーターを水流 の条件および河床材料の性質と結びつける.

$\beta$ については, 式 (4)で与えられるが,たとえば掃流砂 量式として Meyer-Peter and Müller ${ }^{25)}$ 式を採用する と, 次のように水路勾配をパラメーターとした相対水深 の関数として決定される.

$$
\beta=(3 / 2)\left(h_{0} / d\right) /\left[\left(h_{0} / d\right)-0.047(\sigma / \rho-1) / S_{0}\right] \cdots
$$

ここに, $\sigma$ : 礫の密度, $\rho:$ 水の密度である。

$p_{1}, p_{2}$ の決定には，水流の非定常の運動方程式が必要 であるが,ここでは一次元化された式である次の Saint-Venant 方程式を用いる (広幅一様水路).

$$
\beta_{0} \partial U / \partial t-g S_{0}+g \partial h / \partial x+\alpha_{0} U \partial U / \partial x+g S_{f}=0 \cdots \text { (16) }
$$$$
\partial h / \partial t+U \partial h / \partial x+h \partial U / \partial x=0 \cdot
$$

ここで, $U$ : 断面平均流速, $S_{f}$ : 摩擦勾配, $\alpha_{0}$ : エネル ギー係数, $\beta_{0}$ : 運動量係数, $g$ : 重力加速度である.

式（1）で表わされる水深の微小変化を考え，流速も次 のように微小変動をしているとする。

$$
U(x, t)=U_{0}\left[1+\alpha_{U} \eta_{0} \sin \left(\omega t-\chi x-\phi_{U}\right)\right]
$$

式(17)を線形化して用いると, 次の関係が得られる.

$$
\phi_{U}=0 ; \quad \alpha_{U}=\gamma-1 ; \quad \gamma=c / U_{0}
$$

このとき， $\partial U / \partial x, \partial U / \partial t$ は容易に $\partial h / \partial x, \partial h / \partial t$ を用い て書き直すことができ，式(16)は次のように摩擦勾配の 変化を表わす式として書き改められる.

$$
\begin{aligned}
S_{f}=S_{0} & {\left[1+\left\{-\left(\alpha_{U} F r_{0}^{2}+1\right) \frac{\partial h}{\partial x}\right.\right.} \\
& \left.\left.-\frac{\alpha_{U} F r_{0}^{2}}{U_{0} / u_{* 0}} \frac{1}{u_{* 0}} \frac{\partial h}{\partial t}\right\} \frac{1}{S_{0}}\right]
\end{aligned}
$$

ところで，底面せん断応力 $\tau_{b}$ は $\rho g h S_{f}$ と表わされるか
ら，水深の微小変化に対する底面せん断応力の変化は次 のようになる.

$$
\frac{\tau_{b}}{\tau_{b 0}}=1+\frac{h^{\prime}}{h_{0}}+p_{01} \frac{\partial h}{\partial x}+\frac{p_{02}}{u_{* 0}} \frac{\partial h}{\partial t}
$$

ただし，

$$
\begin{aligned}
& p_{01}=-\left(\alpha_{U} F r_{0}^{2}+1\right) / S_{0} \cdots \cdots \\
& p_{02}=-\alpha_{U} F r_{0}^{2}\left(u_{* 0} / U_{0}\right) / S_{0}
\end{aligned}
$$

で与えられ，ここに $F r_{0} \equiv U_{0} / \sqrt{g h_{0}}$ (フルード数)である. 流砂量が底面せん断応力と一対一に関係づけられるなら ば, $p_{1}=p_{01}, p_{2}=p_{02}$ となり, 式 $(9) の \lambda_{0}$ は次のように評 価されることになる。

$$
\lambda_{0}=\left[h_{0} \omega /\left(\gamma u_{* 0}\right)\right]\left[\left(\alpha_{U} F r_{0}\right)^{2}-1\right] /\left(S_{0} C / \sqrt{g}\right)
$$

ここに，Cは Chezy 係数である.上式の概略を Fig. 5 に 示した. $\left[h_{0} \omega /\left(\gamma u_{* 0}\right) /\left(S_{0} C / \sqrt{g}\right)\right]$ が一定のとき, 流砂量変 化の水深変化に対する位相差はフルード数の増加関数と

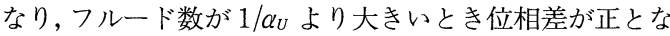
る(遅れ)。礫床流れの抵抗則を，

$$
C / \sqrt{g}=A_{0}(h / d)^{m}
$$

と表わすと, 式(19)より次の関係が得られる。

$$
\alpha_{U}=m+0.5 ; \quad \gamma=m+1.5 \text {. }
$$

Manning-Strickler 式によると $A_{0}=7.66, m=1 / 6$ であ るが，急勾配礫床ではその適用性は必ずしも保証されな ( $^{8)}$.

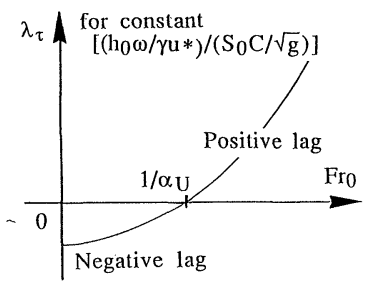

Fig. 5 Phase shift of bed shear stress.

さて，非常に鋭いハイドログラフで，しかも礫のよj に質量の大きい流砂では，慣性効果が無視できない場合 も考えられる．慣性力の効果をも考慮した掃流力相当分 を $\tau_{b E}$ と書くと,

$$
\frac{\tau_{b E}}{\tau_{b 0}}=1+\frac{h^{\prime}}{h_{0}}+p_{01} \frac{\partial h}{\partial x}+\frac{p_{02}}{u_{* 0}} \frac{\partial h}{\partial t}+\psi_{1}-\psi_{2}
$$

で，ここに， $\phi_{1} ， \psi_{2}$ はそれぞれ流体と礫の加速にかかわ る慣性力の抗力に対する比で，次のように表わされる。

$$
\begin{aligned}
\phi_{1} & =\rho C_{M} A_{3} d^{3} \frac{\partial u_{b}}{\partial t} /\left(\frac{1}{2} C_{D} \rho u_{b}^{2} A_{2} d^{2}\right) \cdots \cdots \cdots \cdots . . . \\
\psi_{2} & =\rho\left(\frac{\sigma}{\rho}+C_{M}^{\prime}\right) A_{3} d^{3} \frac{\partial u_{g}}{\partial t} /\left(\frac{1}{2} C_{D} \rho u_{b}^{2} A_{2} d^{2}\right) \cdots
\end{aligned}
$$

ここで, $C_{M}, C_{M}^{\prime}$ : 仮想質量に関する係数, $A_{2}, A_{3}$ : 碟 の形状係数, $C_{D}$ : 抗力係数, $u_{b}$ : 河床近傍流速, $u_{g}$ : 礫 
の移動速度で, $A_{b} \equiv u_{b 0} / u_{* 0}$ とおくと, 慣性力の効果は次 のようにまとめることができる.

$$
\psi \equiv \psi_{1}-\psi_{2}=-\Xi_{0}\left(\frac{C}{\sqrt{g}}\right)^{2} \frac{\alpha_{U}}{A_{b}} \frac{d}{h_{0}} \frac{1}{u_{* 0}} \frac{\partial h}{\partial t}
$$

ここに, $\left.\Xi_{0}=\left[2 A_{3} /\left(C_{D} A_{2}\right)\right]\left[\left(\sigma / \rho+C_{M}^{\prime}\right)-C_{M}\right)\right]$ である。な お式 $(30)$ を得るにあたっては，線形近似による関係， $\partial U / \partial t=\left(\alpha_{U} U_{0} / h_{0}\right)(\partial h / \partial t)$ を用い，また $u_{g}=u_{b}$ と近似し た.

$\tau_{b E}$ が掃流砂量を規定するとすると， $p_{1}, p_{2}$ について, $p_{1}=p_{01}, \quad p_{2}=p_{02}-\left(\Xi_{0} \alpha_{U} / A_{b}\right)\left(d / h_{0}\right)$ ，すなわち，

$$
\begin{aligned}
& p_{1}=-\left(\alpha_{U} F r_{0}^{2}+1\right) / S_{0} \cdots \cdots \cdots \cdots \cdots \cdots \cdots \cdots \cdots \cdots \cdots \cdots \cdots \cdots \cdots \cdots \cdots \cdots \\
& p_{2}=-\left[\alpha_{U} F r_{0}^{2} /(C / \sqrt{g})+\left(\alpha_{U} / A_{b}\right) \Xi_{0}\left(S_{0} d / h_{0}\right)\right] S_{0} \cdots(32)
\end{aligned}
$$

となる.よって, 流砂量の位相差にかかわるパラメーター $\lambda_{0}$ は,

$$
\lambda_{0}=\frac{\omega h_{0}}{\gamma u_{* 0}}\left\{\alpha_{U}^{2} F r_{0}^{2}-\left(1-\frac{\alpha_{U}}{\gamma} \frac{\Xi_{0}}{A_{b}} \frac{C}{\sqrt{g}} \frac{S_{0} d}{h_{0}}\right)\right\} \frac{\sqrt{g}}{S_{0} C}
$$

となる。すなわち, 位相差を決定する無次元パラメーター は, $\omega h_{0} / u_{* 0}, F r_{0}$ および $S_{0} d / h_{0}$ であるということができ る. 式 (33)の概略を Fig. 6 に示す. 流砂量の位相差が負 である場合と正である場合とはフルード数で分かれる が,この限界フルード数は $S_{0} d / h_{0}$ が大きくなるにつれて (勾配が大きくなり相対粗度が大きくなるにつれて)小さ くなり，位相差は正となる場合が多くなる．また，Fr が 一定ならば，位相差は $S_{0} d / h_{0}$ の増加関数となる。

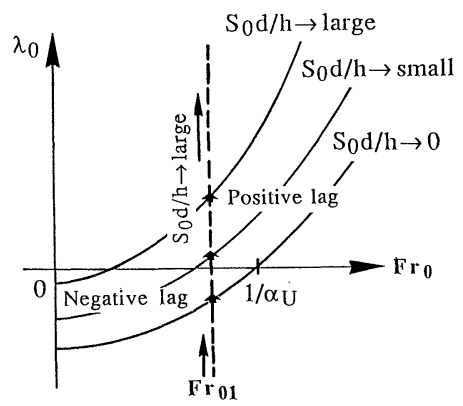

Fig. 6 Phase shift of effective tractive force on bed-load motion.

\section{Graf and Suszka の実験的研究の概要壮3)}

Graf and Suszka ${ }^{8)}$ は, 長さ $17 \mathrm{~m}$, 幅 $0.6 \mathrm{~m}$ の可変勾 配水路に, 中央粒径 $12.2,23.5 \mathrm{~mm}$ の 2 種のほぼ均一な 礫を平坦に敷いたところへ，ほぼ二等辺三角波形の八イ ドログラフをもつ非定常流れを導き（電磁流量バルブを パソコンで制御する方法)，下流端に設けられた自動重量 測定機能（金網製バスケットをワイヤで吊るしその上端 に貼付けられたストレインゲージを利用したもの）のあ る採砂箱にて流砂量の時間的変化を測定した．水路勾配 $\left(S_{0}\right)$ は $0.005 \sim 0.025$ と変化させ，また洪水継続時間

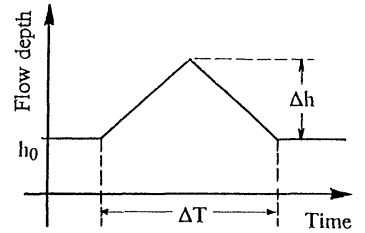

Fig. 7 Schematic figure of hydrograph in laboratory experiments by Graf and Suszka.

Table 1 Experimental condition (Graf and Suszka).

\begin{tabular}{c|c|c|c|c|c|c}
\hline Series & $\begin{array}{c}\text { Number } \\
\text { of cases }\end{array}$ & $\begin{array}{c}\mathrm{d} \\
(\mathrm{cm})\end{array}$ & $\mathrm{S}_{0}$ & $\begin{array}{c}\mathrm{h}_{0} \\
(\mathrm{~cm})\end{array}$ & $\begin{array}{c}\Delta \mathrm{h} \\
(\mathrm{cm})\end{array}$ & $\begin{array}{c}\Delta \mathrm{T} \\
(\mathrm{sec})\end{array}$ \\
\hline 1 & 6 & 12.2 & 0.0050 & $18.9-19.4$ & $5.1-6.8$ & $38.3-266.8$ \\
2 & 6 & 12.2 & 0.0075 & $13.3-13.7$ & $6.0-7.8$ & $40.9-270.6$ \\
3 & 6 & 12.2 & 0.0090 & $11.1-11.8$ & $6.1-8.0$ & $39.1-273.0$ \\
4 & 6 & 12.2 & 0.0100 & $10.4-10.8$ & $6.2-8.1$ & $38.7-271.0$ \\
6 & 6 & 12.2 & 0.0125 & $7.3-7.6$ & $6.1-8.0$ & $37.5-270.9$ \\
7 & 3 & 12.2 & 0.0150 & $6.4-6.6$ & $4.9-5.4$ & $55.5-273.3$ \\
11 & 6 & 23.5 & 0.0150 & $15.0-15.2$ & $5.5-5.9$ & $35.5-266.9$ \\
12 & 6 & 23.5 & 0.0200 & $11.1-11.6$ & $4.1-5.3$ & $33.2-252.0$ \\
13 & 6 & 23.5 & 0.0250 & $9.2-9.7$ & $2.3-3.0$ & $29.9-244.3$ \\
\hline
\end{tabular}

$(\Delta T)$ は, 約 33〜270 秒の間で変化させた. 実験は各 run について 6 回繰り返して再現性の確認を行うとともに, これらの平均值を用いた。 この程度の通水時間では, 初 期に平坦にならされた河床は実験中平坦に保たれる。モ デルとする洪水 (Fig. 7 参照) は，限界掃流力をわずかに 越えた状態をbase-flowとし（その水深を $h_{0}$ で表わ す), ピークの状態は掃流力が base-flow の 1.5 から 2.0 倍程度に設定している (Table 1 参照). 現象を支配する 要素は, base-flow の水深 $\left(h_{0}\right)$ とその付加分 $(\Delta h)$, baseflow の摩擦速度 $\left(u_{* 0}\right)$, 水路勾配 $\left(S_{0}\right)$, 洪水継続時間 $(\Delta T)$ および礫の粒径 $(d)$ である.

実験の結果は先に Fig. 1 に示したように，（1) 実測流 砂量は定常等流を仮定して求めたものより増幅され, (2)粒径が大きく勾配が大きいほど流砂量のピークは八 イドログラフのそれより遅れる傾向にあり，2，３.で 得られた解析結果と定性的に一致している.

Graf and Suszka ${ }^{17)}$ は上述の特性のうち(1)に着目 し，流砂量の増分についての検討を行った．すなわち次 のような非定常指標を定義し，その特性を次元解析的に 検討した。

$$
\varepsilon \equiv\left(V_{s}-V_{s 0}\right) / V_{s 0}
$$

ここに， $V_{s}$ は洪水期間中の累積流砂量の実測值， $V_{s 0}$ は 定常等流を仮定して計算された累積流砂量である. Graf and Suszkaは，この無次元指標と先に述べた支配要素 から作られる無次元量との相関を検討することから， $u_{* 0} \Delta T / \Delta h$ と $S_{0} d / \Delta h$ の 2 つを抽出し, 次の回帰式を得 た.

注 3 ）第 32 回水理講演会論文集 ${ }^{6)}$ でも Graf and Suszka の デー夕に言及しているが, 本論文では礫の流送時の慣性力の効 果を考えることで，現象のより良い説明を可能にしている. 
$\varepsilon=115\left(\Delta h / u_{* 0} \Delta T\right)^{0.5}\left(S_{0} d / \Delta h\right)^{0.5}-0.3$

このとき， $\Delta h$ の効果は事実上消滅している.

\section{5. 線形解析結果と Graf and Suszka の実験 の比較}

実現象や Graf and Suszka の実験8)では非線形効果の 卓越が明らかに予想され, 線形解析の結果をそのまま適 用してこの現象を定量的に記述するのは無意味である が, 線形解析結果が定性的には現象論的説明に役立つこ とはすでに前章でも述べたし，定量的に線形計算が実現 象とどのように懸隔しているかを知ることの意義, 線形 解析で予測される事柄の積極的利用で半経験的には（単 に次元解析的手法を用いるよりは有利に）現象予測を進 められるであろうという利点に鑑みて, 本章では 2 ., 3 . の線形解析結果を Graf and Suszka の実験結果8),17)にあ てはめて比較的検討を進める。

さて，2.の線形正弦波モデルの半周期分をこの実験の 三角波状ハイドログラフの近似として適用すると（Fig. 8 参照, $\left.\Delta T=\pi / \omega, \Delta h / h_{0}=\eta_{0}\right)$, 式(34)の $V_{s}, V_{s 0}$ は, 非定常効果を受けた流砂量, 式 ( 3 )および各時刻で定常 等流を仮定して得られる流砂量, 式（7）の積分によって 次の上うに解析的に求められる.

$$
\begin{aligned}
& V_{s 0}=q_{s 0} \Delta T\left(1+2 \beta \eta_{0} / \pi\right) \cdots \\
& V_{s}=q_{s 0} \Delta T\left(1+2 \alpha_{1} \beta \eta_{0} / \pi\right)
\end{aligned}
$$

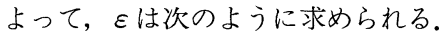

$$
\varepsilon=2 \beta \eta_{0}(\alpha-1) /\left(\pi+2 \beta \eta_{0}\right)
$$

この $\varepsilon を$,

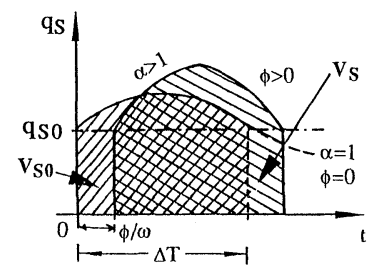

Fig. 8 Model hydrograph.

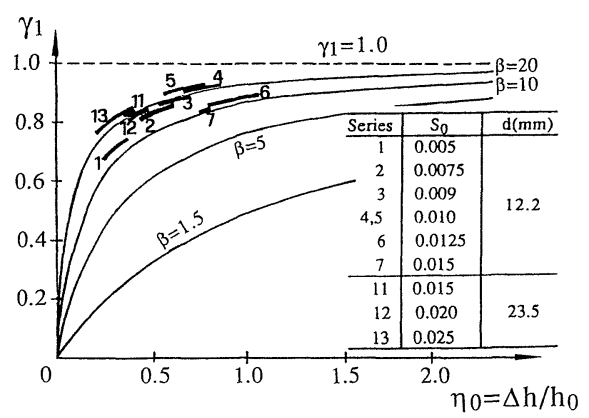

Fig. 9 Relation between $\gamma_{1}$ and $\eta_{0}$.

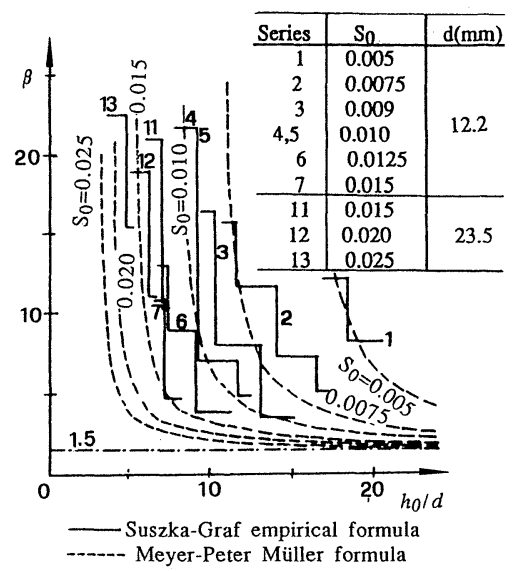

Fig. 10 Relation between $\beta$ and $h_{0} / d$.

$$
\begin{aligned}
& \varepsilon=\gamma_{1} \gamma_{2} \cdots \cdots \cdots \cdots \cdots \cdots \\
& \gamma_{1}=2 \beta \eta_{0} /\left(\pi+2 \beta \eta_{0}\right) \\
& \gamma_{2}=\alpha-1=\sqrt{1+\lambda_{0}^{2}}-1
\end{aligned}
$$

と 2 つの成分に分割すると， $\gamma_{1}$ は（ $\beta$ を規定する） $h_{0} / d$ と $\eta_{0}$ に支配され，他方 $\gamma_{2}$ は3.の結果（式(24)）より主 として $u_{* 0} \Delta T / h_{0}, S_{0} d / h_{0}, F r_{0}$ に支配される.

$\gamma_{1}$ と $\eta_{0}$ の関係を Fig. 9 に示した. Graf らの実験条件 から推定される $\gamma_{1}$ の範囲を太線で示したがシリーズ 1 を除いて $0.8 \sim 0.9$ 程度と $\eta_{0}$ に対しほぼ一定となってい る.すすおち，このため Graf らの回帰式から $\Delta h$ は消滅 する(式(35)）ものと推定される。ところで $\beta$ は式(15) のようにも与えられるが, $q_{s 0}=A h_{0}^{B}$ のような簡単な式を 想定すると $\beta=B$ で, 実際 Suszka $\left.{ }^{8}\right)$ 自らの水路で同じ 河床材料を用いた定常等流下での実験によりこのかたち で $\beta$ を調べており，その結果は水路勾配の大きいとき式 （15）と異なる (Fig. 10 参照)。これは Meyer-Peter Müller 式 ${ }^{25}$ における限界掃流力の設定がもはやここで用い ているような磷に対しては適切でない8)ことによるもの

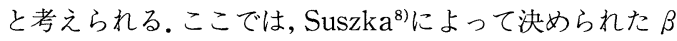
の值を用いた。

$\gamma_{1}$ が Graf らの実験ではほぼ一定值であることがわ かったので, 式(35)に示した $\varepsilon$ にいての回帰式は $\gamma_{2}$ に ついても同じ傾向を示す，先にも述べたよjに式(35)で $\Delta h$ は消滅するからこれを $h_{0}$ と置き換えても変わりな く，このとき式(35)上り Grafらの実験結果は， $\gamma_{2}$ が

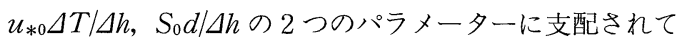
いることと理解され，3．の議論の適用結果と定性的に一 致する（Graf らの実験では $F r_{0}$ はほぼ一定でこの効果 は顕著には現われていない). Graf and Suszka ${ }^{177}$ は，次 元解析的手法で支配パラメーターを予想し, 相関解析か ら最終的に式(35)を得たのであるが， $u_{* 0} \Delta T / \Delta h$ はとも かく, $S_{0} d / \Delta h$ 支配の物理的意味は見出せなかったし， 
$\Delta h / h_{0}$ の重要性が現象論的には重要視されるにもかかわ らず最終的に回帰式から消滅したことなどの問題点がこ こに示した線形解析で解消されたことがわかる.

式(33)を，ここでの対象に対して書き直すと，

$$
\Psi \equiv \frac{u_{*_{0}} \Delta T}{h_{0}} \lambda_{0}=K_{1}\left\{K_{2} \frac{S_{0} d}{h_{0}}-\left(1-\alpha_{U}^{2} F r_{0}^{2}\right)\right\}
$$

ただし，

$$
\begin{aligned}
& K_{1}=\left(\pi / S_{0}\right) /(C / \sqrt{g}) / \gamma \cdots \\
& K_{2}=\left(\alpha_{U} \Xi_{0} / A_{b}\right)(C / \sqrt{g}) \gamma
\end{aligned}
$$

となる.

Graf and Suszka の実験データ8)より，ハイドログラ フのピークと流砂量のピークの時間差 $(\delta t)$ から位相差 $\phi_{1}$ を読み取って検討した. $\Delta T$ がせいぜい数 100 秒で, 特に実際非定常効果の出現しているものは数 10 秒のも のであることから $\delta t$ を正確に求めることが難しく, 読み 取られたデー夕はばらつきも大きく精度が悪いのはやむ を得ない.得られた位相差はたかだか $0.15 \pi$, ほとんどが $0.1 \pi$ 以下であるから $\lambda_{0}=\phi_{1}$ と近似される。このように して得られる $\Psi$ に相当する値を $S_{0} d / h_{0}$ に対してプロッ トしたのがFig. 11 である. 式 (42) と定性的に一致して いることは容易にわかる. 係数 $K_{1}, K_{2}$ やそれにかかわる 諸係数の正確な值はいまのところ評価できないがオ一 ダ一的には, $K_{1} \cdot K_{2}=5 \sim 10$ 程度であり, 本解析では位相

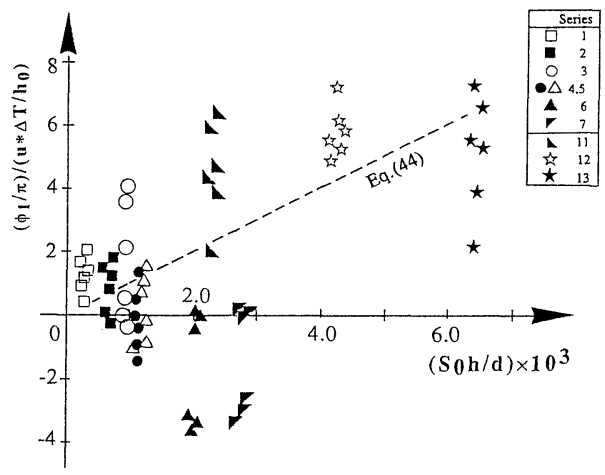

Fig. 11 Relation between $\left(\phi_{1} / \pi\right)\left(\mathrm{u} *{ }_{0} \Delta \mathrm{T} / \mathrm{h}_{0}\right)$ and $\mathrm{S}_{0} \mathrm{~d} / \mathrm{h}_{0}$.

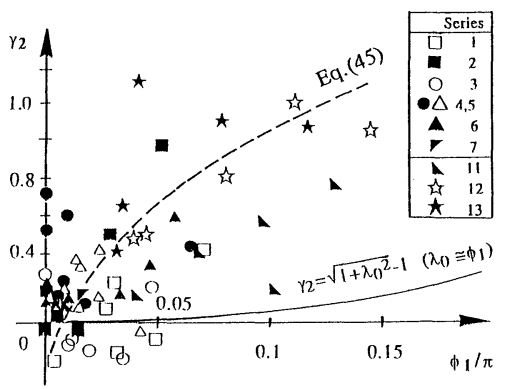

Fig. 12 Relation between $\gamma_{2}$ and $\phi_{1}$.



Fig. 13 Relation between $\gamma_{2}$ and $u_{* 0} \Delta T / h_{0}$.

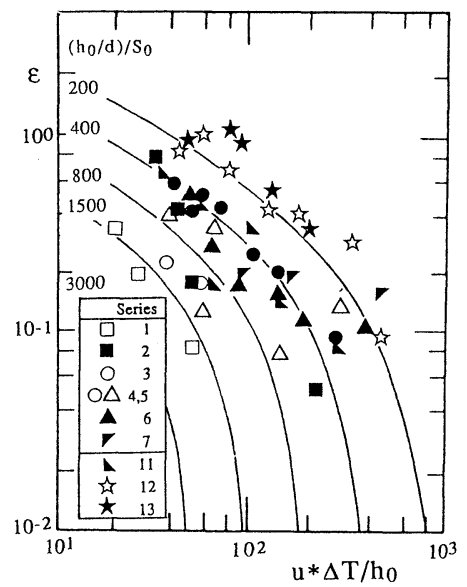

Fig. 14 Relation between $\varepsilon$ and $u_{* 0} \Delta T / h_{0}$.

差が相当に過小評価されることがわかる.

また, 位相差 $\phi_{1}$ と Graf and Suszka ${ }^{17)}$ が導入したパラ メーターをの 1 成分である $\gamma_{2}$ との関係をプロットした のがFig. 12 である. 定性的にこれらが式(41)と同様に 強い正の相関を有することは検証されるものの, 定量的 には今回用いた線形関係式は使用に耐えない程度に過小 評価することがわかり，ここの点でも非線形性を考慮し た取扱いが望まれよう。

上記の検討の結果, 線形解析結果は支配パラメーター と, それが現象に正に相関するか負に相関するかは論じ られても, 定量的評価としてはかけ離れたものとなる. このことは理論的には非線形解析の必要を意味するが, 工学的にはこうした線形解析結果の長所を積極的に利用 して実験デー夕の回帰を図るのが有利と考之る非4.

Graf and Suszka の実験8)では大きな の位相差をもっているときに出現していることから，第 
0 次近似的に式(42) と Fig. 11 とから,

$$
\phi_{1} / \pi=K_{3}\left(S_{0} d / h_{0}\right) /\left(u_{* 0} \Delta T / h_{0}\right)
$$

ただし $K_{3}=1000$ 程度とする. 次に, 位相差の小さいデー 夕は負の位相のものも含むことからたとえば $\phi_{1} / \pi<$ 0.01 の領域を度外視して, Fig. 12 より $\gamma_{2}$ と $\phi_{1} / \pi$ の間に 次のような実験式を作るとする.

$$
\gamma_{2}=K_{4} \sqrt{\phi_{1} / \pi}-0.3
$$

ここで $K_{4}=4.0$ 程度である.このとき， $\gamma_{2}$ について次の 式が得られる。

$$
\gamma_{2}=K_{5}\left(S_{0} d / h_{0}\right)^{0.5}\left(u_{* 0} \Delta T / h_{0}\right)^{-0.5}
$$

なお, $K_{5}=125$ 程度である.この式を実験データとともに 示したのがFig. 13 である. Graf らの実験では, 先に述 べたように $\gamma_{1}$ がほぼ一定で 0.9 程度であることを考慮 すると，この式から得られる の推定式は Graf and Suszka ${ }^{17)}$ が提案した式(35)にほとんど一致することに なる(Fig. 14 参照). 㛜密には, 実験式 (45), (46)の定式 化をより丁寧に行うべきであろうが，ここではあえて Graf and Suszka の実験式 ${ }^{17)}$ の帰着を優先した. Graf らのデータ8)は， $\gamma_{2}$ がほとんど一定になること, baseflow のフルード数がほぼ一定であることなど, 条件が限 られており，ここではそれに限って議論したが，線形理 論ですら異なる条件では異なる性状の現われることが推 測される，逆にいえば，線形理論は Graf and Suszkaの 回帰式の適用限界を示唆するものでもあると理解でき る.

\section{6.あとがき}

本研究で得られた結果を要約すると次のとおりであ る.

（1）本研究で扱う鋭いハイドログラフに対する平坦 礫床での掃流砂量の非定常特性は, 緩い勾配の砂河床の それと大きく異なることを従来の典型的な実験例から指 摘した. 前者は主として流れの非定常性の掃流機構に対 する直接作用であるのに対し，後者は河床の変形に要す る時間遅れが卓越した現象である。このことを水深の正 弦波状時間・空間変化に対する線形解析で明確に示した. 前者では, 流砂量変化は水深の時間的変化に対し正また は負の位相を示して量的には増幅されるのに対し, 後者 では流砂量は抑制され常に位相が遅れる。

注 4 ）以下の近似的あるいは便宜的な非定常効果の予測方 法については, 第 32 回水理講演会6)で提案しているが, ここで はそれを詳細な線形解析を行った結果と絡めて位置づけした ものである。
（2）非定常流れを一次元運動量方程式で記述し，さ らに水と礫の運動に対する慣性力を考慮して, 線形解析 の枠組みの中で, さらに詳しく礫の流砂量に対する非定 常効果を調べた。この結果, 勾配と相対水深の比および フルード数が大きいほど正の位相差 (遅れ)が出現しやす い.また位相の正・負にかかわらず，非定常現象の時間 スケールの無次元量と位相差の絶対值は反比例する.こ れらの結果は礫床での実験結果と定性的に一致する。

（3）非定常流れのもとでの流砂量の増幅効果を表わ

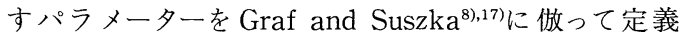
し, 線形解析の枠組みのもとで評価した。この結果, 増 幅効果 $(\varepsilon)$ には定常流砂量式の関数形の効果（相対水梁 の効果として現われる）を表わす $\gamma_{1}$ と，（2）で検討した 位相差にかかわる分（位相差の絶対値とともに増加する 分）を表わす $\gamma_{2}$ とに区分して検討するのが適当であるこ とがわかった. 前者については水梁の変動振幅の無次元 值とともに増加する。

（4）正弦波の 1 つの山（半周期分）を 1 つの洪水の ハイドログラフの近似とみなして, 線形解析結果と Graf and Suszka の実験結果 ${ }^{8), 17)}$ との比較を行った. 線形解析 は次のような実験結果と定性的に一致する. 非定常効果 $\varepsilon の j ち \gamma_{1}$ は Graf らの実験ではたまたま一定值をと る. $\gamma_{2}$ は流砂量の位相差の絶対值の増加関数となる. 位 相差の絶対值は洪水の無次元化された時間スケールに反 比例する. 流砂量の位相は, Graf らの実験ではbaseflow のフルード数がほぼ一定であったため, 水路勾配と 相対水深の比に比例して増加, この比の小さいときは負 の值をとる（Grafらのデータは base-flow のフルード 数が大きいため, 負の位相の出現例は比較的少なかっ た).

（5）上述の実験結果と解析結果を比較したとき， $\gamma_{2}$ について定量的には解析結果がかなりの過小評価となっ ている。

（6）非線形現象が線形解析で定量的に予測できない ことは当然であるが, 現象に潜む機構の記述として支配 パラメーターとその定性的支配動向が保証されることを 積極的に利用し, 必要な定量評価は経験的に定式化する というアプローチを提案した（純粋に次元解析と相関解 析手法によるGraf らの研究17)では，支配パラメーター の抽出理由が単に高相関であることのみによっていた ク，実験条件の特殊性などが系統的に明らかにならず， 得られる回帰式は内挿でしかなくなる).この手法で, 限 られた条件でGraf らが自ら示した回帰式17)を得ること が可能であったし，条件の異なる場合への外挿的予測も 可能と考えられる。 
謝辞: 本研究は, 主として著者がスイス連邦工科 大学ローザンヌ校(E.P.F.L.)に滞在中 (1987 年度)に行っ たもので, E.P.F.L.に招へいし，この研究の機会を与えて 頂いた W.H. Graf 教授にまず深甚の謝意を表わす. 本研 究は E.P.F.L.での L. Suszka 氏（現・ポーランド科学ア カデミ一研究員）を中心として行われた実験的研究を補 完するもので，その意味では, Graf 教授, Suszka 氏との 共同研究の一部である.Graf 教授からはさまざまな有益 な助言を頂いた．また実験・デー夕処理の詳細について 教示いただき, 再実験や，本解析にかかわるデー夕解析 に協力いただいた Suszka 氏およびE.P.F.L.水理実験室 (LHYDREP) のスタッフ一同にも深く感謝する次第で ある。

1) Jain, S.C. : Sediment transport under nonequilibrium conditions, Proc. NATO Workshop on Movable Bed Physical Models, De Voorst Laboratory, Delft Hydraulics, The Netherlands, 1987.

2) Di Silvio, G. : Adaptation process through the surface of sedimentary streams, Euromech 215, Mechanics of Sediment Transport in Fluvial and Marine Environments, St. Margherita, Italy, 1987.

3) Yen, B.C. : Significance of nonuniform, unsteady and nonequilibrium conditions in fluvial channels, Proc. Int. Conf. on Fluvial Hydraulics, Budapest, Hungary, pp. 112 118, 1988.

4) Klaassen, G.J. : On time scales of transient processes in rivers, Proc. Int. Conf. on Fluvial Hydraulics, Budapest, Hungary, pp. 343 360, 1988.

5）辻本哲郎・森 明巨・岡部健士 - 大本照憲：流砂の非平 衡の論理とその応用, 第 33 回水理講演会論文集, pp. 445 461, 1989.

6）辻本哲郎・W.H. グラフ：流れの非定常性の掃流砂量へ の影響, 第 32 回水理講演会論文集, pp. 395 400, 1988.

7) Tsujimoto, T., Graf, W.H. and Suszka, L.: Bed-load transport in unsteady flow, Proc. 6th Cong. APDIAHR, Kyoto, Vol. II, pp. 15 22, 1988.

8) Suszka, L.: Sediment transport at steady and unsteady flow; A laboratory study, Doctoral Thesis, No. 704, Ecole Polytechnique Fédérale de Lausanne, Switzerland, 1988.

9) Henderson, F.M. : Open Channel Flow, Macmillan, London, 1966.

10）本間 云・安芸咬一編：物部水理学, 岩波書店, 1962.

11）日野幹雄: 明解水理学, 丸善, 1983 .
12）林 泰造・大島正憲：Kinematic wave としての洪水の 非定常性が水流の乱れ構造に及ぼす影響の研究, 第 32 回 水理講演会論文集, pp. $607 \sim 612,1988$.

13) Nordin, C.F.: Aspects of flow resistance and sediment transport, Rio Grande near Bernallilo, New Mexico, USGS Water Supply Paper, 1498-H, 1964.

14) Guy, H.P.: An analysis of some storm-period variables affecting stream sediment transport, US Geol. Surv. Prof. Pap. 462-E, 1964.

15) Phillips, B.C. and Sutherland, A.J. : Spatial and temporal lag effects in bedload transport, Res. Rep. No. 84-10, University of Canterbury, New Zealand, 339p., 1984.

16) Phillips, B.C. and Sutherland, A.J.: Numerical modelling of spatial and temporal lag effects in bed load transport, Proc. 21st Cong. IAHR, Merbourne, Australia, Vol. 3, pp. 571 576, 1985.

17) Graf, W.H. and Suszka, L.: Unsteady flow and its effect on sediment transport, Proc. 21st Cong. IAHR, Merbourne, Australia, Vol. 3, pp. 539 544, 1985.

18) Suszka, L. and Graf, W.H.: Sediment transport in steep channels at unsteady flow, Proc. 22nd Cong. IAHR, Lausanne, Switzerland Fluvial Hydraul., pp. 166 170, 1987.

19) Freds $\phi$ e, J.: Unsteady flow in straight alluvial streams-Modification of individual dunes, J. Fluid Mech., Vol. 91, pp. 497 512, 1979.

20）中川博次・辻本哲郎：Lower regimeにおける非定常移 動床流れの抵抗の遅れ性状, 第 25 回水理講演会論文集, pp. $1 \sim 7,1981$.

21) Tsujimoto, T. and Nakagawa, H. : Unsteady behaviour of dunes, Channels and Channel Control Structures (edited by K.V.H. Smith), Springer-Verlag, Berlin, pp. 85 99, 1984.

22) Paul, T.C. and Dhillon, G.S. : Effect of unsteady flow on sediment transport, Proc. 22nd Cong. IAHR, Lausanne, Fluvial Hydraul., pp. 148 153, 1987.

23) Tingsanchali, T. and Rana, M.Y.: Sediment bed load in steady non-uniform flow, Proc. 22nd Cong. IAHR, Lausanne, Fluvial Hydraul., pp. 171 176, 1987.

24) Yalin, M.S. and Bishop, C.T. : On the physical modelling of dunes, Proc. 17th Cong. IAHR, Baden-Baden, F.R.G., Vol. 1, pp. 25 32, 1977.

25) Meyer-Peter, E. and Müller, R. : Formulas for bedload transport, Proc. 2nd Cong. IAHR, Stockholm, Sweden, pp. $39 \sim 64,1948$.

(1989.7.17・受付) 